\title{
An Analysis of the Sources of Wheat Output Growth in the Barani Area of the Punjab ${ }^{1}$
}

\author{
Munir AHMAD and AZKAR AHMAD
}

\begin{abstract}
A time-varying efficiency effects approach using district level data of wheat in barani Punjab is used to disintegrate wheat output growth into different sources. The results show that wheat output grew at an annual rate of 2.71 percent under barani conditions, during the period of study. Technological change was the main driving force, sharing about 107 percent of this growth, while the changing inputs contributed negatively by about 10 percent and the efficiency contribution was less than 4 percent. On the other hand, irrigated output increased by about 4.7 percent per annum in the region; of which 65 percent, 1.3 percent, and 34 percent were attributable to technological change, change in efficiency, and increase in inputs. As regards the overall wheat output in the barani region of the Punjab, it grew at an annual rate of 2.97 percent- 84 percent of which was shared by the barani lands and the remaining 16 percent was contributed by irrigated lands in the region.

One common result which was observed under both barani and irrigated conditions was that the productivity growth (the sum of technological and efficiency change) showed declining trends exclusively due to negative trends in technical efficiency. Low relative profitability as compared to growing vegetables and raising livestock might be the main cause of this trend in the barani area: the same reason could also be a source of decline in efficiency. Rapid technological advancements require that farmers and administrators improve their management skills even to keep the productive efficiency at the same level. This is not possible without education and training along with a more effective flow of information [Lall (1993)]. Under these circumstances, the agricultural extension system has to play a greater role in assisting the farming community in the barani areas so as to adopt and use new technologies more rationally.
\end{abstract}

\section{INTRODUCTION}

Agriculture is the largest sector of Pakistan economy. It accounts for about 24 percent of the GDP of Pakistan. It provides employment to more than 50 percent of

Munir Ahmad is Senior Research Economist and Azkar Ahmad is Staff Economist at the Pakistan Institute of Development Economics, Islamabad.

Authors' Note: We would like to thank Dr Sarfraz Khan Qureshi, Director, PIDE, and Dr M. Ghaffar Chaudhry, Joint Director, PIDE, for their helpful comments. We are indebted to Mr Annice Mahmood, Senior Faculty Member of the Institute, for his advice. We are also thankful to an anonymous referee of this journal for suggesting improvements in an earlier version of this paper.

${ }^{1}$ The term 'barani' refers to the agricultural area that depends on rainfall for cultivation. The word 'barani' comes from the Persian word 'baran’ meaning 'rain' [Qureshi (1963)]. 
the labour force and contributes directly or indirectly to about 70 percent to the total export earnings of the country. The agriculture sector has two main components, which are crop production and livestock products. Crops share about 70 percent of the agricultural GDP and the remaining 30 percent comes from the livestock sector.

A large number of crops are grown in Pakistan: the most important of them are wheat, rice, cotton, and sugarcane, which jointly contribute nearly 75 percent to the value-added from the crop sector. Among these, wheat is at the top in terms of its share both in value-added and cropped area, which are 33 percent and 42 percent respectively [Pakistan (1998)].

The Punjab province dominates in wheat production and shares more than 70 percent both in area and output. About one-fifth of the cultivated area of Punjab is rainfed and the most fertile region is the Pothwar, which is located north of the Salt Range stretching from the river Jehlum to the river Indus. It covers the areas of Attock, Rawalpindi, Jehlum, and Chakwal. It shares about 10 percent of the wheat area in Punjab. Despite low yield, it contributes about 6 percent to the total wheat production of the province. This contribution makes the difference between selfsufficiency and import for the country. Therefore, the development of the rainfed area is very important for the country's food security.

To exploit the full potential of the barani lands, the Government of Pakistan has initiated a number of measures which are mentioned here briefly. Apart from input-output price incentives, infrastructure development, agricultural extension, etc., the government efforts include the establishment of a National Agricultural Research Centre, the Barani Agricultural College - to be raised to university level, the Agency for Barani Area Development, etc., whose mandate is to work solely in barani area agriculture. Due to these efforts, the Pothwar area experienced significant increase in wheat yield in the last three decades, i.e., $150 \mathrm{~kg} / \mathrm{hac}$ in $1970-71$ to almost $600 \mathrm{~kg} / \mathrm{hac}$ in 1996-97. As a consequence, total production of this area increased considerably during this period.

It is to be noted that the tubewell irrigation in the Pothwar region has increased over time: the share of wheat area under irrigation increased from 4.7 percent in 1971 to 7.3 percent in 1997. Thus, the overall increase in wheat output is partly fuelled by the popularity of tubewell irrigation in the region.

Two main sources that could lead to expansion in agricultural production are productivity growth and the use of additional factors of production [Ahmad and Bravo-Ureta (1995)]. Productivity has two constituents: technological change and technical efficiency [Good et al. (1993)]. Research and development is considered to be the main force behind technological change, while, education, experience, and expanded infrastructure are consequential for improving the system's efficiency [Kalirajan (1991) and Fan (1991)].

The major objective of this paper is to analyse the barani wheat output growth from three perspectives: technological change, technical efficiency, and input 
growth. At present, about 7 percent of the total wheat area in Pothwar is under well irrigation and, thus, a similar analysis is also conducted to compute irrigated wheat share in the overall growth of the region. ${ }^{2}$ This study is the first attempt to decompose wheat output growth into these components using Pakistani data. ${ }^{3}$ The remaining paper is arranged in three sections. Section 2 deals with the methodological issues and estimation procedure. Section 3 presents the variable definitions and data. The results are discussed in Section 4, while concluding remarks are given in Section 5.

\section{FRONTIER ANALYSIS AND OUTPUT GROWTH}

Farrell (1957) initially introduced the frontier function technique. This original work was of a non-parametric type. It was extended to parametric techniques, including deterministic and stochastic models for the measurement of efficiency. The deterministic models were initiated by Aigner and Chu (1968) and further extended by Timmer (1970, 1971); Afriat (1972); Richmond (1974); Schmidt (1976) and Greene (1980). The main drawback of the deterministic model is that it does not allow the possible effects of the factors that are not under the control of the producer. Consequently, all deviations from the frontier can be regarded as inefficiency, resulting in an over-estimation of this component [Meeusen and van den Broeck (1977)].

To avoid this problem the stochastic frontier model was independently developed by Aigner, Lovell, and Schmidt (1977) and Meeusen and van den Broeck (1977). This model appends an error term, assuming two components: one is symmetric, capturing statistical noise and random shocks, and the other is one-sided, representing technical inefficiency effects. This approach was initially developed for the analysis of cross-sectional data. However, it was later expanded to analyse

${ }^{2}$ We thank the anonymous referee for this suggestion after reading the first version of the paper.

${ }^{3} \mathrm{An}$ only exception is a study published in this journal is by Karamat and Hameed (1996) which used aggregate country level data of both agriculture and manufacturing sectors of Pakistan. The efficiency component was not properly estimated in this study. Estimation of time variant technical efficiency and its changes over time involve some further steps: the authors stopped at Equation 4 (in the present paper), while to compute technical efficiency and the changes over time one has to proceed through Equations 5 and 6. Other study using aggregate level data for Pakistan agriculture related to total factor productivity and technical change analysis is by Wizarat (1981). These studies do not incorporate the efficiency component in their analyses.

Qureshi (1963) analysed the impact of rainfall on acreage and production in the barani area of West Pakistan (using the data from Pothwar area). No other independent variable was included in the analysis. However, the results, though old, could provide an interesting comparison to that of the present study. Recently, Mahmood (1995) and Himayatullah (1995) used cross-sectional data for barani wheat. Mahmood (1995), using the profit function approach, concluded that barani farming is subject to risky conditions and thus the objective function in this situation is to ensure food security rather than pursuing the economic efficiency, and barani farming is subject to constant returns to scale. Himayatullah (1995) concluded that the medium-sized farms are more efficient than small and large farms. This study further concludes that among the tenurial status farms, owner-operated farms have higher productivity than the other categories. 
balanced [e.g., Pitt and Lee (1981) and Battese and Coelli (1988)] and unbalanced [e.g., Battese, Coelli and Colby (1989) and Seale (1990)] panel data. All of these studies relied on the assumption that technical efficiency does not vary over time. Kumbhakar (1990) relaxed this assumption using balanced panel, while Battese and Coelli (1992) extended this approach to accommodate unbalanced panel data.

The stochastic frontier models are not free of criticism. These models require distributional assumptions regarding the composed error term to separate efficiency from statistical noise and thus have the tendency to produce different efficiency measures [Schmidt and Sickles (1984)]. Additionally, this technique does not allow the likely association between technical efficiency and the other variables included in the frontier function. These problems can be taken care of by using the fixed effects model [Gong and Sickles (1989) and Schmidt and Sickles (1984)].

Hoch (1955) pioneered the fixed effects technique: its subsequent extensions could be found in Hoch $(1958,1962)$; Mundlak (1961, 1978) and Schmidt and Sickles (1984). All of these developments were based on the assumption that technical efficiency is time-invariant. However, Mundlak (1978) was the first who proposed that this assumption could be relaxed. Recently, Cornwell, Schmidt, and Sickles (1990) formally developed a fixed effects technique that allows the firm effects to vary over time. The same technique has been applied for the analysis of data in this paper.

Among the numerous functional forms, the most widely used in the empirical studies relating to efficiency are the translog and Cobb-Douglas forms [Bravo-Ureta and Pinheiro (1993) and Battese (1992)]. The Cobb-Douglas functional form is used for the analysis in this study, ${ }^{4}$ which can be written as

$$
L n Y_{i t}=\alpha+\sum_{k} \beta_{k} \ln X_{k i t}+\gamma T+\varepsilon_{i t} \quad \ldots \quad \ldots \quad \ldots \quad \ldots
$$

Where subscripts $i, t$, and $k$ represent the ith firm (here district), time and inputs, respectively; $Y_{i t}$ denotes output and $X_{k i t}$ stands for $k$ th input; $T$ is smooth time representing technological change; In denotes natural log; and $\alpha, \beta$ and $\gamma$ are the unknown parameters to be estimated. The term $\varepsilon_{i t}=U_{i}+V_{i t}$ is a composed error term: where $V_{i t}$ is stochastic random variable representing factors which are not under the control of the producer, which is assumed to be independent and identically distributed with mean zero and constant variance; and $U_{i}$ is an indicator of technical efficiency [Greene (1990)]. Following Mundlak (1961) and Hoch (1962), along with the assumption that technical efficiency is to remain constant over time, Equation 1 can be rewritten as

$$
\operatorname{LnY} Y_{i t}=\alpha+\Sigma_{k} \beta_{k} \ln X_{k i t}+\gamma T+\Sigma_{i} \delta_{i} D_{i}+V_{i t} \quad \ldots \quad \ldots \quad \ldots
$$

${ }^{4}$ The translog production function was also estimated which resulted into several violations of regularity conditions. However, the results of some of the empirical studies also show that technical efficiency measures are unaffected by alternative functional forms [e.g., Ahmad and Bravo-Ureta (1996)]. 
Where $D_{i}$ is a district-specific dummy variable having a value of 1 for the ith district and 0 otherwise. The model given in Equation 2 can be estimated using analysis of variance technique or least squares with dummy variables [Greene (1990)]. The $\delta_{i}$ can be used to compute firm-specific technical efficiency as $T E_{i}=\exp \left(\delta_{i}\right) / \max$ $\left[\exp \left(\delta_{i}\right)\right]^{5}$

Following Mundlak's (1978) proposal, $U_{i}$ in Equation 2 can be replaced with $\theta_{\mathrm{i}}+\rho_{\mathrm{i}} T$ in order to allow the firm effects to vary over time. However, Cornwell, Schmidt, and Sickles (1990) suggested the following function

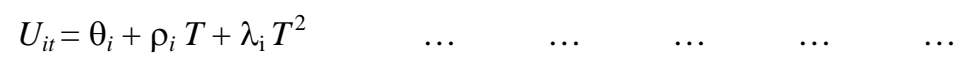

Where $\theta_{i}$ is a district-specific intercept, $\rho_{i}$ is district-specific parameter with respect to time, and $\lambda_{i}$ is a firm-specific parameter with respect to time squared. Following Cornwell, Schmidt, and Sickles (1990), time-varying technical efficiency can be estimated in two steps. In the first step, residuals $\left(\varepsilon_{i t}\right)$ are derived using OLS from Equation 1 [Fecher and Pestieau (1993)]. In the second step, $\varepsilon_{i t}$ is regressed on district-specific dummies, time, and their combination, as follows:

$$
\varepsilon_{i t}=\Sigma_{i} \theta_{i} D_{i}+\Sigma_{i} \rho_{i} D_{i} T+\Sigma_{i} \lambda_{i} D_{i} T^{2}+V_{i t} \quad \ldots \quad \ldots \quad \ldots \quad \ldots
$$

where $V_{i t} \sim N\left(0, \sigma_{v}{ }^{2}\right)$. The predicted values from Equation 4 (i.e., $U_{i t}$ ) are then used to calculate $T E$ measures at all data points as follows:

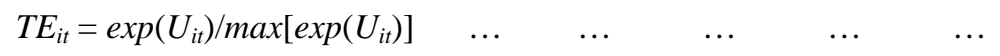

where $\max \left[\exp \left(U_{i t}\right)\right]$ is the highest fitted value in the th time period.

The model just discussed is further used to disintegrate the sources of wheat output growth in the Pothwar area of Punjab. These sources of growth are the size effect, technological change, and technical efficiency. For the purpose of exposition, the estimated Cobb-Douglas production function in a simplified version can be written as

$$
\ln Y=\ln \hat{B}_{t}+\ln T \hat{E}_{i t}+\sum_{k} \hat{B}_{k} \ln X_{K i t} \quad \ldots \quad \ldots \quad \ldots \quad \ldots
$$

The right-hand side of this equation shows three components. The first component, $\ln \hat{B}_{i t}$, stands for technological change and is equal to $\hat{\alpha}+\hat{\gamma} T$. The second term, $\ln T \hat{E}_{i t}$, represents technical efficiency. The third expression, $\sum_{K} \hat{B}_{K} \ln X_{K i t}$, is the size effect. The total derivative of Equation 6 with respect to time produces

Technical efficiency (TE) of a production unit (here, district) is a ratio of observed output to the maximum achievable output, at the given level of inputs [Lovell (1993)]. If $T E=1$, the productive unit is on the frontier of the production function and thus is 100 percent technically efficient. The $T E<1$ means that the productive unit lies below the frontier production function and consequently produces less than the maximum potential output. So, to achieve the maximum possible output, more inputs have to be used - which in turn involve a higher cost. 


$$
\frac{d \ln Y_{i t}}{d T}=\frac{\partial \ln \hat{B}_{t}}{\partial T}+\frac{\partial \ln \hat{E}_{i t}}{d T}+\sum_{K} \hat{B}_{K} \frac{\partial \ln X_{K i t}}{d T} \quad \ldots \quad \ldots \quad \ldots
$$

In simple notations, the above equation can be rewritten as

$$
\frac{\dot{Y}}{Y}=\frac{\dot{B}}{B}+\frac{T \dot{E}}{T E}+\sum_{K} \hat{B}_{K}\left(\frac{\dot{X}}{X}\right) \quad \ldots \quad \ldots \quad \ldots \quad \ldots \quad \ldots
$$

The dots in Equation 8 indicate time derivatives. The term on the left-hand side of this equation, $\dot{Y} / Y$, stands for output growth. This, in turn, is composed of technological change ( $\dot{B} / B$ ), change in technical efficiency ( $T \dot{E} / T E$ ), and change in the level of inputs or size effect $\left[\sum_{K} \hat{B}_{K}(\dot{X} / X)\right]$. From the estimated model, all of these three sources of growth can be obtained as follows: (1) $\hat{\gamma}$ approximates the technological change component, $\dot{B} / B$; (2) $\ln T \hat{E}_{i t}-\ln T \hat{E}_{i t-1}$ yields the change in technical efficiency, $T \dot{E} / T E$; and (3) the expression $\sum_{K} \hat{B}_{K}\left(\ln X_{K i t}-\ln X_{K i t-1}\right)$ is used to estimate the size effect, $\sum_{K} \hat{B}_{K}(\dot{X} / X)$.

The above procedure is used separately for the non-irrigated and irrigated wheat production. To compute overall average growth rate in the region, the following formulation is used:

$$
\dot{P} / P=s_{u}\left(\dot{Y}_{u} / Y_{u}\right)+s_{i}\left(\dot{Y}_{i} / Y_{i}\right) \ldots \quad \ldots \quad \ldots \quad \ldots \quad \ldots
$$

The left-hand side of this equation shows the overall wheat growth rate in the region. The first and the second terms on the right-hand side of the equation are growth rates of non-irrigated and irrigated wheat weighted by respective shares in total wheat production.

\section{VARIABLE DEFINITIONS AND DATA}

Time-series data for the period of 1970-71 to 1996-97 from four districts of the barani area of Punjab are used in this study. These districts are Attock, Rawalpindi, Jehlum, and Chakwal. Chakwal district was created in the early 1980s; however, the Bureau of Agricultural Statistics started reporting information about this district from the crop year 1984-85. Pooling the data from four of these districts resulted into an unbalanced panel consisting of 94 observations. The sources of data include various issues of Agricultural Statistics [Pakistan (Various Issues)] and Punjab Development Statistics [Punjab (Various Issues)]. 
The analysis of this study relies on a single-equation production function. The dependent variable is total wheat output in thousand maunds-non-irrigated or irrigated output. The input variables include total fertiliser used in nutrient tones, ${ }^{6}$ area under wheat in thousand acres-irrigated and non-irrigated areas in respective equations. The third input used in the model is that of rainfall in millimetres: Since the study uses the aggregate production function, the rainfall variable is multiplied by the respective area under wheat to get availability of total quantum of rainfall in a particular crop season in th year. In our opinion, if this adjustment is not made, the resulting parameter estimate of the area under wheat will be overor under-estimated according to the impact of rainfall, which is expected to be positive in this study. ${ }^{7}$

\section{EMPIRICAL RESULTS}

Equation 1 is estimated using LIMDEP version 7 both for non-irrigated and irrigated wheat production functions and the results are reported in Table 1, which is the first step in the estimation of technical efficiency. The adjusted $R^{2}$ values of the models are 0.55 and 0.78 , indicating 55 percent and 78 percent of the variations in the barani and irrigated wheat outputs, respectively, in the Pothwar area and are explained by the variables included in the production functions.

The coefficient for acreage in the barani equation is 0.5331 , and is statistically significant at the 1 percent probability level—the magnitude of the coefficient implies an increase of about 5.3 percent in output by increasing the area under wheat by 10 percent, keeping all other inputs constant. On the other hand, the area coefficient in the irrigated equation is 0.9121 , and is also statistically highly

${ }^{6}$ Separate data regarding the use of fertiliser on non-irrigated and irrigated crops were not available. However, the farm level surveys indicate that the chemical fertiliser use on irrigated wheat crop is 100 percent higher than that of the use on the non-irrigated wheat farms [e.g., NFDC (1996)]. Consequently, to apportion the fertiliser use on the irrigated wheat acres (Ferti), the following formulation has been used:

Ferti $=[($ irrigated area $* 2) /($ irrigated area $* 2+$ non-irrigated area $)] *$ Total fertiliser use.

${ }^{7}$ Assume the following multiplicative aggregate production function:

$$
Y=A X_{1}^{b 1} X_{2}^{b 2} X_{3}^{b 3} X_{4}^{b 4}
$$

Multiplying the left-hand side of this equation with $\left(X_{4} / X_{4}\right)$ and the right-hand side with $\left(X_{4} / X_{4}\right)^{b 1}$, $\left(X_{4} / X_{4}\right)^{b 2}$ and $\left(X_{4} / X_{4}\right)^{b 3}$ will yield :

$$
\left(Y / X_{4}\right)=A\left(X_{1} / X_{4}\right)^{b 1}\left(X_{2} / X_{4}\right)^{b 2}\left(X_{3} / X_{4}\right) X_{4}{ }^{b 1+b 2+b 3+b 4-1=\theta}
$$

It is clear from the above equation that even if the production function is based on per acre basis, the parameter estimates will remain the same as those of the aggregate. The only difference it makes is that of the estimate of the land variable. This coefficient (now $\theta$ ) represents the returns to scale, ranging from -ive to +ive values: it exhibits decreasing, constant, or increasing returns to scales if $\theta$ is equal to 0 , -ive, or +ive, respectively. If we go back to the original function but partially as

$$
Y=A X_{1}^{b 1} X_{2}^{b 2}\left(X_{3} / X_{4}\right)^{b 3} X_{4}^{b 3+b 4}
$$

then the parameter estimate of $X_{4}$ will be $b_{3}+b_{4}$. Using this analogy, if rainfall is used as such, it will result in over-estimation of the parameter estimate of the land variable. 
Table 1

Parameter Estimates of the Barani and Irrigated Wheat Production Functions

\begin{tabular}{lccccc}
\hline Variables & \multicolumn{2}{c}{ Barani Production Function } & & \multicolumn{2}{c}{ Irrigated Production Function } \\
\cline { 2 - 3 } \cline { 5 - 6 } & Coefficients & $t$-ratio & & Coefficient & $t$-ratio \\
\hline Constant & -0.4654 & -1.323 & & -0.4435 & -3.368 \\
Area & $0.5331^{\mathrm{a}}$ & 4.805 & & $0.9121^{\mathrm{a}}$ & 13.775 \\
Fertiliser & 0.0378 & 0.965 & & $0.0622^{\mathrm{b}}$ & 2.047 \\
Rain & $0.2122^{\mathrm{a}}$ & 4.372 & & $0.0908^{\mathrm{a}}$ & 2.96 \\
Time & $0.0289^{\mathrm{a}}$ & 4.271 & & $0.0304^{\mathrm{a}}$ & 5.95 \\
Adj. $R^{2}$ & \multicolumn{2}{c}{0.53} & & \multicolumn{2}{c}{0.78} \\
\hline
\end{tabular}

Note: The data were tested for the auto-correlation problem: DW statistics were found very low-1.33 and 1.02 for the barani and irrigated equations, respectively—showing the problem of auto-correlation. To correct this problem Cochrane-Orcutt procedure was used [Ramanathan (1992)]. The resulting DW statistics, 1.78 and 1.86 for the respective equations, show no auto-correlation problem.

${ }^{a}$ Significant at 1 percent significance level; ${ }^{b}$ significant at the 5 percent level of significance.

significant. The irrigated acreage coefficient shows almost 100 percent higher response than that of the barani acreage. Its magnitude implies about 9 percent increase in wheat output by increasing 10 percent wheat area under irrigation.

The coefficient of the fertiliser in barani equation is 0.0378, showing an increase of about 3.8 percent in wheat output with 10 percent increase in the use of fertiliser. However, the impact appears to be statistically non-significant. One of the main reasons for this non-significant effect is the total dependence of fertiliser applications and utilisation on the rain moisture, which is highly variable and generally inadequate during the wheat crop season in barani areas of Punjab. ${ }^{8}$ Among the chemical fertilisers, nitrogen and phosphorus are the most commonly used nutrients in wheat production. According to Khan (1985), the nitrogen is chemically mobile in nature and becomes quickly available to the plants whether it is applied at the time of seeding or is top-dressed at the tillering. However, its utilisation totally relies on the soil moisture. On the other hand, phosphorous is chemically immobile in nature and so gets fixed up in the soil complex and slowly becomes available to the plants; its utilisation depends on the availability of rain moisture at various stages of the plant growth. Consequently, the use of fertiliser in barani wheat is not as effective as is under the irrigated conditions. It is clearly evidenced by the fertiliser coefficient in the irrigated equation that is 0.0622 , which is not only double the size of the barani wheat equation but is also statistically significant.

The coefficient of rainfall in barani wheat equation is 0.2122 , indicating that output increases by 2.1 percent with a 10 percent increase in rainfall and the impact

${ }^{8} \mathrm{New}$ high-yielding varieties require about 16 inches delta of water, while the rainfall in barani areas of Punjab ranges from a low of less than 4 inches in dry years to a maximum of 16 inches in the wettest years during the wheat crop season. 
is statistically highly significant. While the coefficient of rainfall in the irrigated equation is 0.0908: Although the impact is statistically significant, the magnitude of the coefficient is even less than half of its counterpart in the barani equation. This difference is justified on the grounds that the most of the plants' water requirement is being fulfilled by the assured water supply in irrigated fields; as a result, the marginal contribution of rainfall in irrigated wheat production is relatively less than that of in the barani case.

The coefficients for time in both the equations are statistically significant at the 1 percent significance level. The magnitude of the coefficient in the barani equation is 0.0289 , showing an annual increase of about 2.9 percent in wheat output due to technological progress. While, the coefficient of time in irrigated equation is 0.0304, implying about 3 percent increase in output resulting from technological progress. The proximity of both of these parameter estimates shows that advancements in technologies for the region are equally accessible and adopted by the rainfed and irrigated farms. The technological change components in both the equations turned out to be very high. This has become possible probably due to higher use of tractor technology in the barani areas-which helps better levelling of the soil, timely conservation of rain moisture, uniform seeding, and timely sowing of the crop. According to Khan (1985), tractor cultivation in barani areas has shown an increase of up to 30 percent higher yield of wheat as compared to the traditional tillage with cow or donkey. Timely sowing of wheat crop greatly helps in achieving higher production potential: the research results show that the yield of wheat reduces up to $240 \mathrm{~kg} / \mathrm{ha}$ for every 15 days delay in sowing after the optimum planting period of October 20 to November 20 in barani area [Khan (1985)]. Adoption of highyielding, short-duration, and drought-resistant varieties was another crucial factor that has also substantially contributed to wheat output growth, since these varieties have the potential to use limited soil moisture more efficiently. ${ }^{9}$

Technical efficiency measures are obtained using Equations 4 and 5 and the results are given in Table 2. These results in the barani case show that the average efficiencies of districts Attock, Rawalpindi, Jehlum, and Chakwal, respectively, are $0.89,0.84,0.88$, and 0.88 ; while the efficiency measures for the respective districts in the case of irrigated wheat are $0.89,0.87,0.89$, and 0.90 . The comparison of efficiency measures across the districts and between barani and irrigated cases shows that all the districts except Rawalpindi have achieved approximately the equal level of production potential. One of the main causes behind the Rawalpindi district to be technically less efficient could be that of its proximity to the bigger milk, meat, and vegetable markets in the twin cities. Since the wheat crop is

${ }^{9}$ Continuous time series data for tractors and area under high-yielding varieties are not available. However, agricultural census and farm machinery census data indicate that there is about 5-fold increase (from 1975 to 1994) in farm tractors in the Pothwar region. The area under high-yielding varieties also increased by about 5 times during this period. 
Table 2

Technical Efficiency Measures

\begin{tabular}{|c|c|c|c|c|c|c|c|c|c|c|c|}
\hline \multirow[b]{2}{*}{ Year } & \multicolumn{5}{|c|}{ Technical Efficiency Non-irrigated } & \multicolumn{6}{|c|}{ Technical Efficiency Irrigated } \\
\hline & $\overline{\text { Attoc }}$ & Rpindi & Jehlu & Chakwa & Average & $\overline{\text { Attoc }}$ & Rpindi & Jehlu & Chakwa & & $\overline{\text { age }}$ \\
\hline 1972 & 0.73 & 0.65 & 0.72 & & 0.70 & 0.80 & 0.74 & 0.78 & 0.77 & & 0.77 \\
\hline 1973 & 0.77 & 0.69 & 0.76 & & 0.74 & 0.82 & 0.76 & 0.80 & 0.80 & & 0.80 \\
\hline 1974 & 0.81 & 0.72 & 0.80 & & 0.77 & 0.85 & 0.79 & 0.83 & 0.82 & & 0.82 \\
\hline 1975 & 0.84 & 0.75 & 0.83 & & 0.81 & 0.88 & 0.81 & 0.84 & 0.84 & & 0.84 \\
\hline 1976 & 0.87 & 0.77 & 0.86 & & 0.84 & 0.90 & 0.83 & 0.86 & 0.86 & & 0.86 \\
\hline 1977 & 0.90 & 0.80 & 0.89 & & 0.86 & 0.92 & 0.85 & 0.88 & 0.88 & & 0.88 \\
\hline 1978 & 0.92 & 0.83 & 0.92 & & 0.89 & 0.93 & 0.87 & 0.90 & 0.90 & & 0.90 \\
\hline 1979 & 0.95 & 0.85 & 0.94 & & 0.91 & 0.95 & 0.89 & 0.91 & 0.92 & & 0.92 \\
\hline 1980 & 0.96 & 0.87 & 0.96 & & 0.93 & 0.96 & 0.90 & 0.92 & 0.93 & & 0.93 \\
\hline 1981 & 0.98 & 0.89 & 0.97 & & 0.95 & 0.97 & 0.92 & 0.93 & 0.94 & & 0.94 \\
\hline 1982 & 0.99 & 0.90 & 0.98 & & 0.96 & 0.97 & 0.93 & 0.94 & 0.95 & & 0.95 \\
\hline 1983 & 1.00 & 0.91 & 0.99 & & 0.97 & 0.98 & 0.93 & 0.95 & 0.95 & & 0.95 \\
\hline 1984 & 1.00 & 0.92 & 0.99 & & 0.97 & 0.98 & 0.94 & 0.95 & 0.95 & & 0.95 \\
\hline 1985 & 1.00 & 0.92 & 0.99 & & 0.97 & 0.97 & 0.94 & 0.95 & 0.96 & & 0.96 \\
\hline 1986 & 0.99 & 0.93 & 0.98 & 0.86 & 0.94 & 0.96 & 0.94 & 0.95 & 0.96 & 1.00 & 0.96 \\
\hline 1987 & 0.98 & 0.92 & 0.97 & 0.89 & 0.94 & 0.95 & 0.94 & 0.95 & 0.96 & 0.98 & 0.96 \\
\hline 1988 & 0.97 & 0.92 & 0.95 & 0.91 & 0.94 & 0.94 & 0.94 & 0.95 & 0.95 & 0.97 & 0.95 \\
\hline 1989 & 0.95 & 0.91 & 0.93 & 0.92 & 0.93 & 0.92 & 0.93 & 0.94 & 0.94 & 0.95 & 0.94 \\
\hline 1990 & 0.93 & 0.90 & 0.91 & 0.92 & 0.91 & 0.91 & 0.92 & 0.94 & 0.92 & 0.93 & 0.92 \\
\hline 1991 & 0.91 & 0.89 & 0.88 & 0.92 & 0.90 & 0.88 & 0.91 & 0.93 & 0.91 & 0.91 & 0.91 \\
\hline 1992 & 0.88 & 0.87 & 0.85 & 0.91 & 0.88 & 0.86 & 0.89 & 0.92 & 0.89 & 0.90 & 0.89 \\
\hline 1993 & 0.85 & 0.85 & 0.81 & 0.89 & 0.85 & 0.84 & 0.88 & 0.90 & 0.87 & 0.88 & 0.87 \\
\hline 1994 & 0.82 & 0.83 & 0.78 & 0.87 & 0.82 & 0.81 & 0.86 & 0.89 & 0.85 & 0.85 & 0.85 \\
\hline 1995 & 0.78 & 0.80 & 0.74 & 0.84 & 0.79 & 0.78 & 0.84 & 0.87 & 0.83 & 0.83 & 0.83 \\
\hline 1996 & 0.75 & 0.77 & 0.70 & 0.81 & 0.76 & 0.75 & 0.82 & 0.85 & 0.81 & 0.81 & 0.81 \\
\hline 1997 & 0.71 & 0.74 & 0.66 & 0.77 & 0.72 & 0.72 & 0.79 & 0.84 & 0.78 & 0.79 & 0.78 \\
\hline Average & 0.89 & 0.84 & 0.88 & 0.88 & 0.87 & 0.89 & 0.87 & 0.90 & 0.89 & 0.90 & 0.89 \\
\hline Minimum & 0.71 & 0.65 & 0.66 & 0.77 & 0.70 & 0.72 & 0.74 & 0.78 & 0.77 & 0.79 & 0.77 \\
\hline Maximum & 1.00 & 0.93 & 0.99 & 0.92 & 0.97 & 0.98 & 0.94 & 0.95 & 0.96 & 1.00 & 0.96 \\
\hline
\end{tabular}

relatively unprofitable as compared to raising livestock and growing vegetables, the farmers pay less attention to manage wheat farms.

The results given in Table 2 indicate that the average technical efficiency measures in the recent years ranges from 66 percent to 84 percent. This implies that wheat output could be increased by about 16 percent to 34 percent with the given technology and resource base. To exploit this production potential from the existing resources, the agricultural extension system has to play a greater role in assisting the 
farming community in order to improve their management capabilities, so that they could adopt and use new technologies more effectively.

The results given in Table 2 also indicate that technical efficiency increased in all the districts up to the early 1980s, stagnated during the mid-1980s, and declined thereafter. However, the declining trend is observed in Chakwal district throughout the study period in the irrigated case; while, in the barani case, efficiency increased till 1992 and declined thereafter.

For the purpose of output growth decomposition, Equation 8 has been used and the results for barani wheat are reported in Table 3, while the results for the irrigated case are presented in Table 4. The results for barani wheat show that during the study period wheat output increased at an annual growth rate of 2.71 percent. Technological change turned out to be the major source behind this growth, i.e., 2.89 percent. The share of inputs in this annual increase is negative -0.28 percent, while the technical efficiency contribution to the overall growth in wheat output is observed to be 0.10 percent per annum. In spite of higher technological change, the negative trends in efficiency in recent years, as could be seen from the table, resulted in negative productivity growth, which is the sum of technological progress and growth in technical efficiency.

The negative rate of barani wheat output growth that stems from the changing inputs $(-0.28$ percent) is further decomposed into its constituent factors that are fertiliser, rains, and area under wheat. The results given in Table 3 indicate that the fertiliser contribution is 0.47 percent and the favourable rains share growth in output at about 0.32 percent; while, the area under barani wheat is declining over time and thus pushing the rate of growth in output by a significant amount, measuring -0.87 percent per annum—resulting in net input effect to be negative.

The results also show that the total barani wheat output increased by about 70 percent during the study period. Of this total growth, 75 percent and 3 percent are attributable to technological change and improvement in technical efficiency, respectively. While, inputs contributed negatively to output growth. These figures again witness that technological change has been the main source of increase in total barani wheat output in the Pothwar region.

On the other hand, the results given in Table 4 show that the irrigated output increased at the faster rate, that is, of 4.70 percent per annum. Again, the technological progress is the main driving force, i.e., 65 percent, inputs effect stands second by contributing about 34 percent, and improvement in technical efficiency stands at the third place, with a contribution of only 1.28 percent. However, the results in irrigated wheat also show that the change in technical efficiency has turned into a negative trend from a +3.24 percent in 1972-73 to -3.01 percent in 1996-97. This implies that, despite high technological progress, productivity growth has become almost zero in the recent years. As regards the contributing factors to the inputs component of the growth (i.e., 1.6 percent), the increase in irrigated area 
Table 3

Wheat Output Growth Decomposition in Barani Area

\begin{tabular}{|c|c|c|c|c|c|c|c|}
\hline \multirow[b]{2}{*}{ Year } & \multicolumn{4}{|c|}{ Output Growth Decomposition } & \multicolumn{3}{|c|}{ Input Growth Decomposition } \\
\hline & $\begin{array}{l}\text { Total } \\
\text { Growth }\end{array}$ & $\begin{array}{l}\text { Technolo } \\
\text { Change }\end{array}$ & $\begin{array}{l}\text { T.Effici } \\
\text { Change } \\
\end{array}$ & $\begin{array}{c}\text { Inputs } \\
\text { Changes }\end{array}$ & $\begin{array}{c}\text { Change } \\
\text { Area }\end{array}$ & $\begin{array}{l}\text { Change } \\
\text { Fertiliser }\end{array}$ & $\begin{array}{c}\text { Change } \\
\text { Rain }\end{array}$ \\
\hline 1973 & 23.47 & 2.89 & 4.94 & 15.64 & 2.80 & 1.10 & 11.74 \\
\hline 1974 & -16.19 & 2.89 & 4.53 & -23.61 & -0.96 & -1.21 & -21.44 \\
\hline 1975 & 21.12 & 2.89 & 4.12 & 14.11 & 0.40 & 0.21 & 13.50 \\
\hline 1976 & 14.25 & 2.89 & 3.71 & 7.65 & -0.18 & 2.18 & 5.65 \\
\hline 1977 & -27.12 & 2.89 & 3.30 & -33.30 & -0.60 & 0.60 & -33.30 \\
\hline 1978 & 28.00 & 2.89 & 2.88 & 22.22 & 1.92 & -1.11 & 21.42 \\
\hline 1979 & 12.16 & 2.89 & 2.47 & 6.79 & 0.00 & 1.84 & 4.96 \\
\hline 1980 & 13.68 & 2.89 & 2.06 & 8.73 & 0.26 & 1.04 & 7.43 \\
\hline 1981 & 6.93 & 2.89 & 1.65 & 2.39 & -0.88 & -0.56 & 3.83 \\
\hline 1982 & 1.88 & 2.89 & 1.24 & -2.25 & 1.13 & 0.54 & -3.92 \\
\hline 1983 & 6.86 & 2.89 & 0.83 & 3.14 & 0.13 & -0.03 & 3.04 \\
\hline 1984 & -21.63 & 2.89 & 0.42 & -24.94 & -5.26 & 0.94 & -20.62 \\
\hline 1985 & -14.71 & 2.89 & 0.01 & -17.61 & -18.65 & -0.77 & 1.80 \\
\hline 1986 & 15.12 & 2.89 & -3.08 & 15.31 & 1.81 & 0.66 & 12.83 \\
\hline 1987 & -0.99 & 2.89 & 0.04 & -3.91 & 1.64 & 0.99 & -6.55 \\
\hline 1988 & -11.73 & 2.89 & -0.44 & -14.19 & -13.03 & -0.73 & -0.43 \\
\hline 1989 & 4.80 & 2.89 & -0.92 & 2.83 & 9.30 & -0.01 & -6.46 \\
\hline 1990 & 10.70 & 2.89 & -1.41 & 9.21 & -0.90 & 0.37 & 9.74 \\
\hline 1991 & 4.98 & 2.89 & -1.90 & 3.99 & 0.76 & -0.61 & 3.84 \\
\hline 1992 & -2.16 & 2.89 & -2.39 & -2.66 & -0.42 & 0.81 & -3.05 \\
\hline 1993 & 0.87 & 2.89 & -2.89 & 0.87 & 2.60 & 0.92 & -2.65 \\
\hline 1994 & -21.16 & 2.89 & -3.39 & -20.66 & -5.46 & -0.64 & -14.56 \\
\hline 1995 & 14.82 & 2.89 & -3.89 & 15.82 & 2.10 & -0.86 & 14.58 \\
\hline 1996 & 2.46 & 2.89 & -4.40 & 3.97 & 0.54 & 0.86 & 2.56 \\
\hline 1997 & -15.58 & 2.89 & -4.90 & -13.57 & 0.35 & -1.10 & -12.82 \\
\hline $\begin{array}{l}\text { Annual } \\
(\%)\end{array}$ & $\begin{array}{l}2.71 \\
(100)\end{array}$ & $\begin{array}{c}2.89 \\
(106.64)\end{array}$ & $\begin{array}{c}0.10 \\
(3.69)\end{array}$ & $\begin{array}{c}-0.28 \\
(-10.33)\end{array}$ & -0.87 & 0.27 & 0.32 \\
\hline $\begin{array}{l}\text { Total } \\
(\%)\end{array}$ & $\begin{array}{l}70.35 \\
(100) \\
\end{array}$ & $\begin{array}{c}75.14 \\
(106.81) \\
\end{array}$ & $\begin{array}{c}2.57 \\
(3.65) \\
\end{array}$ & $\begin{array}{c}-7.36 \\
(-10.46) \\
\end{array}$ & -22.65 & 6.98 & 8.31 \\
\hline
\end{tabular}


Table 4

Wheat Output Growth Due to Irrigation

\begin{tabular}{|c|c|c|c|c|c|c|c|}
\hline \multirow[b]{3}{*}{ Year } & \multicolumn{4}{|c|}{ Output Growth Decomposition } & \multicolumn{3}{|c|}{ Input Growth Decomposition } \\
\hline & Total & Technolo & T.Effici & Inputs & Change & Change & Change \\
\hline & & & Change & Changes & & Fertiliser & \\
\hline 1973 & 31.75 & 3.04 & 3.24 & 25.47 & 15.85 & 3.09 & 6.54 \\
\hline 1974 & -0.66 & 3.04 & 2.98 & -6.68 & 3.61 & -2.00 & -8.29 \\
\hline 1975 & -5.27 & 3.04 & 2.71 & -11.02 & -15.58 & -0.03 & 4.59 \\
\hline 1976 & 28.48 & 3.04 & 2.44 & 23.00 & 14.57 & 4.66 & 3.76 \\
\hline 1977 & -13.37 & 3.04 & 2.18 & -18.59 & -5.11 & 1.44 & -14.92 \\
\hline 1978 & 29.50 & 3.04 & 1.91 & 24.55 & 16.24 & -2.78 & 11.09 \\
\hline 1979 & 9.68 & 3.04 & 1.64 & 5.00 & 0.00 & 3.23 & 1.76 \\
\hline 1980 & -3.87 & 3.04 & 1.38 & -8.29 & -10.04 & 0.41 & 1.34 \\
\hline 1981 & 1.82 & 3.04 & 1.11 & -2.33 & -2.62 & -1.03 & 1.32 \\
\hline 1982 & 3.32 & 3.04 & 0.84 & -0.56 & -0.59 & 0.99 & -0.96 \\
\hline 1983 & 7.00 & 3.04 & 0.58 & 3.38 & 1.15 & 0.43 & 1.80 \\
\hline 1984 & 8.70 & 3.04 & 0.31 & 5.35 & 10.60 & 2.59 & -7.83 \\
\hline 1985 & -22.28 & 3.04 & 0.04 & -25.36 & -26.66 & -0.69 & 1.99 \\
\hline 1986 & 29.21 & 3.04 & 1.00 & 25.17 & 14.22 & 1.35 & 9.60 \\
\hline 1987 & -7.00 & 3.04 & -0.76 & -9.28 & -5.57 & 0.79 & -4.50 \\
\hline 1988 & -4.83 & 3.04 & -0.99 & -6.89 & -5.28 & -1.39 & -0.21 \\
\hline 1989 & 10.79 & 3.04 & -1.21 & 8.96 & 12.04 & 0.26 & -3.34 \\
\hline 1990 & 13.35 & 3.04 & -1.44 & 11.74 & 4.31 & 0.72 & 6.72 \\
\hline 1991 & -2.78 & 3.04 & -1.66 & -4.15 & -5.18 & -0.66 & 1.69 \\
\hline 1992 & -3.34 & 3.04 & -1.89 & -4.49 & -4.14 & 0.62 & -0.98 \\
\hline 1993 & 7.64 & 3.04 & -2.12 & 6.72 & 7.94 & 1.39 & -2.62 \\
\hline 1994 & -15.23 & 3.04 & -2.34 & -15.93 & -7.37 & -0.22 & -8.34 \\
\hline 1995 & 9.95 & 3.04 & -2.57 & 9.47 & 2.71 & -2.01 & 8.78 \\
\hline 1996 & 4.99 & 3.04 & -2.79 & 4.74 & 2.39 & 1.65 & 0.70 \\
\hline 1997 & -7.18 & 3.04 & -3.01 & -7.21 & 2.61 & -1.66 & -8.16 \\
\hline $\begin{array}{l}\text { Annual } \\
(\%)\end{array}$ & $\begin{array}{r}4.70 \\
(100)\end{array}$ & $\begin{array}{c}3.04 \\
(64.68)\end{array}$ & $\begin{array}{c}0.06 \\
(1.28)\end{array}$ & $\begin{array}{c}1.60 \\
(34.04)\end{array}$ & 0.77 & 0.49 & 0.34 \\
\hline $\begin{array}{l}\text { Total } \\
\text { (\%) }\end{array}$ & $\begin{array}{r}122.26 \\
(100)\end{array}$ & $\begin{array}{l}79.04 \\
(64.65)\end{array}$ & $\begin{array}{c}1.59 \\
(1.30)\end{array}$ & $\begin{array}{l}41.62 \\
(34.04)\end{array}$ & 20.11 & 12.72 & 8.79 \\
\hline
\end{tabular}

under wheat shares about 0.77 percent; 0.49 percent is attributable to growth in fertiliser use and 0.34 percent is shared by favourable rains.

Overall growth in wheat output in the region is also calculated using Equation 9 and the results are reported in Table 5. The results show that total wheat output in the region increased at an annual rate of about 2.97 percent- 84 percent (i.e., 2.49) of this growth is shared by the growth in barani wheat production and only 16 percent is attributable to improvement in irrigated wheat output. 
Table 5

Weighted Average Growth Rates

\begin{tabular}{lrrr}
\hline Year & Irrigated Growth & Barani Growth & Average Growth \\
\hline 1973 & -0.06 & 21.46 & 21.40 \\
1974 & -0.50 & -14.66 & -15.16 \\
1975 & 2.23 & 19.46 & 21.70 \\
1976 & -1.59 & 12.56 & 10.97 \\
1977 & 3.87 & -23.56 & -19.69 \\
1978 & 1.28 & 24.30 & 25.58 \\
1979 & -0.41 & 10.85 & 10.44 \\
1980 & 0.17 & 12.37 & 12.54 \\
1981 & 0.32 & 6.26 & 6.58 \\
1982 & 0.73 & 1.68 & 2.41 \\
1983 & 0.82 & 6.21 & 7.03 \\
1984 & -2.49 & -19.21 & -21.71 \\
1985 & 3.53 & -12.94 & -9.41 \\
1986 & -0.84 & 13.31 & 12.48 \\
1987 & -0.45 & -0.90 & -1.34 \\
1988 & 1.00 & -10.65 & -9.65 \\
1989 & 1.98 & 4.09 & 6.07 \\
1990 & -0.41 & 9.10 & 8.68 \\
1991 & -0.44 & 4.33 & 3.89 \\
1992 & 1.02 & -1.87 & -0.85 \\
1993 & -2.17 & 0.74 & -1.43 \\
1994 & 1.59 & -17.77 & -16.18 \\
1995 & 0.64 & 12.92 & 13.56 \\
1996 & -0.80 & 2.19 & 1.39 \\
1997 & 0.66 & -13.40 & -12.75 \\
Average & 0.48 & 2.49 & 2.97 \\
(\%) & $(16.16)$ & $(83.84)$ & $(100)$ \\
\hline
\end{tabular}

The results discussed above indicate that both barani and irrigated production growth analyses show almost similar trends. There are various reasons for the negative trends in efficiency in the region and the total area under wheat in general and under barani wheat in particular. ${ }^{10}$ The first reason could be that of relative unprofitability of the crop concerned as compared to other enterprises. Besides, the published sources of data and the market trends show that a significant amount of area in the rabi season is being diverted towards growing more vegetables and irrigated wheat, which has become possible due to the increased availability of

${ }^{10}$ Irrigated area shows an increasing trend. However, the irrigated wheat area is only 6 percent of the total wheat area and, consequently, this increase is less than the decline in area under barani wheat. 
underground water in the Pothwar region. We are also of the opinion that due to rapid urbanisation and, consequently, higher demand for meat and milk, the farmers in the Pothwar area grow more fodder crops that require a higher quantity of water. ${ }^{11}$ The second reason that could be considered for this trend is that due to small farm size and risky climatic conditions, most of the farming in the Pothwar region is parttime [Khan et al. (1990)], which might lead to lower productive efficiency.

The rapid advancements in biological, chemical, and mechanical technologies themselves could be a third important cause of this declining trend in efficiency. New technologies are becoming increasingly complex and require exploration, experimentation, education and frequent training, regular contact within the farming community, and an effective flow of technical information [Lall (1993)]. Such activities and links are considered to be deficient for the agriculture sector as a whole [Azhar (1993)], and, thus, the barani area is no exception. Moreover, during the periods of rapid scientific advancements, the administrators (farmers) are required to strengthen their management capabilities and skills so as to adopt and use complex technologies more rationally even to keep the productive efficiency at the static level [Lall (1993)].

\section{CONCLUSION AND POLICY IMPLICATIONS}

The main objective of the study is to disintegrate the sources of wheat output growth in the barani area of the Punjab. At presently, about 7 percent of the wheat area in Pothwar is under well irrigation and, thus, a similar analysis is also conducted to compute irrigated wheat share in the overall growth of the region. Overall wheat output grew by 2.97 percent per annum, of which 84 percent was attributable to the growth in barani wheat and the remaining 16 percent was shared by the irrigated output.

The results show that the major driving growth factor was technological change under both conditions, which contributed about 107 percent of the total change in barani output and about 65 percent in irrigated output. The change in efficiency and inputs, respectively, contributed about 3.7 percent and -10.3 percent in barani and 1.3 percent and 34 percent in irrigated wheat.

The results further revealed that the reduction in system efficiency caused productivity growth to decline over the period of study: annual growth in productivity decreased from almost +8 percent to -2 percent under barani conditions and from 6.3 percent to zero percent under the irrigated system during the study period. The effects of reduction in area under barani wheat were greater than the positive effects of fertiliser and rainfall in barani conditions causing the net output effect attributable to inputs to be negative (i.e., -0.28 percent). While the input effect under irrigated conditions was positive (1.6 percent); of which, 0.77 percent, 0.49 percent, and 0.34 percent were attributable to marginal increase under irrigated area, higher use of fertiliser, and favourable rains, respectively.

${ }^{11}$ The data regarding the rabi fodder in Pothwar area are not available from any published source. 
Profitability analysis of various agricultural enterprises was not the objective of the paper. However, we speculate that the main reason for the reduction in area under wheat is its low relative profitability as compared to growing vegetables and raising livestock. The same reason could also be a source of declining efficiency. Moreover, under rapid technological advancements, the farmers and the administrators need to be educated and trained along with a more effective flow of information to maintain efficiency even at the same level [Lall (1993)]. These results lead us to conclude that the agricultural extension system in its linkages with the research departments has to play a greater and effective role in assisting the farming community of the barani areas to improve their managerial potential, so that they could adopt and use new technologies more rationally.

Furthermore, there is a dire need to increase the water use efficiency in the rainfed areas, since the performance of farming relies on seasonal rains: good rain results in higher output and poor rains lead to poor crops. Moreover, the ensured supply of other inputs along with reasonable input-output price structure is also essential to curb the downward trend in area under wheat.

\section{REFERENCES}

Afriat, S. N. (1972) Efficiency Estimation of Production Functions. International Economic Review 13: 568-98.

Ahmad, Munir, and Boris E. Bravo-Ureta (1995) An Econometric Decomposition of Dairy Output Growth. American Journal of Agricultural Economics 77: 914-921.

Ahmad, Munir, and Boris E. Bravo-Ureta (1996) Technical Efficiency Measures for Dairy Farms Using Panel Data: A Comparison of Alternative Model Specifications. The Journal of Productivity Analysis 7: 399-415.

Aigner, D. J., C. A. K. Lovell, and R. J. Schmidt (1977) Formulation and Estimation of Stochastic Frontier Production Function Models. Journal of Econometrics 6: 2137.

Aigner, D. J., and S. F. Chu (1968) On Estimating the Industry Production Function. American Economic Review 58: 826-839.

Azhar, B. A. (1993) Stagnation in Food Grain Production in Pakistan: Evidence, Causes and Prospects. The Pakistan Development Review 32:4 789-97.

Battese, G. E. (1992) Frontier Production Function and Technical Efficiency: A Survey of Empirical Applications in Agricultural Economics. Agricultural Economics 7: 185-208.

Battese, G. E., and T. J. Coelli (1988) Production of Firm Level Technical Efficiencies with a Generalised Frontier Production Function and Panel Data. Journal of Econometrics 38: 387-389.

Battese, G. E., and T. J. Coelli (1992) Frontier Production Functions, Technical Efficiency and Panel Data, with Application to Paddy Farmers in India. The Journal of Productivity Analyses 3: 153-169. 
Battese, G. E., T. J. Coelli, and T. C. Colby (1989) Estimation of Frontier Production Functions and Efficiencies of Indian Farms Using Panel Data from ICRISAT's Village Level Studies. Journal of Quantitative Economics 5: 327-248.

Bravo-Ureta, Boris E., and A. E. Pinheiro (1993) Efficiency Analysis of Developing Country Agriculture: A Review of the Frontier Function Literature. Agricultural and Resource Economic Review 22: 88-101.

Cornwell, C., P. Schmidt, and R. C. Sickles (1990) Production Frontier with CrossSectional and Time-Series Variation in Efficiency Levels. Journal of Econometrics 46: 185-200.

Fan, S. (1991) Effects of Technological Change and Institutional Reform on Production Growth in Chinese Agriculture. American Journal of Agricultural Economics 73: 266-75.

Farrell, M. J. (1957) The Measurement of Productive Efficiency. Journal of Statistical Society Series A 120: 253-281.

Fecher, F., and Pestieau (1993) Efficiency and Competition in O.E.C.D Financial Services. In H. O. Fried, C. A. K. Lovell, and Schmidt (eds) The Measurement of Productive Efficiency Techniques and Applications. New York: Oxford University Press. 374-385.

Gong, B. H., and R. C. Sickles (1989) Finite Sample Evidence on the Performance of Stochastic Frontier Models Using Panel Data. The Journal of Productivity Analysis 3: 229-261.

Good, D. H., M. I. Nadiri, Lars-Hendrik Roller, and R. C. Sickles (1993) Efficiency and Productivity Growth: A Comparison of European and US Air Carriers: A First Look at the Data. The Journal of Productivity Analysis 4: 115-125.

Greene, W. H. (1980) Maximum Likelihood Estimation of Econometric Frontier Function. Journal of Econometrics 13: 27-56.

Greene, W. H. (1990) Econometric Analysis. New York: Macmillan Publishing Co.

Himayatullah (1995) Estimating Relative Technical Efficiency in Barani Agriculture: Some Further Results. The Pakistan Development Review 34:4 913-24.

Hobbs, P. R., A. Razzaq, N. I. Hashmi, B. R. Khan, and B. M. Khan (1989) Wheat Production and Yields in Rawalpindi District of the Punjab from 1983 to 1986. (PARC/CIMMYT Paper No.89-2.)

Hoch, I. (1955) Estimation of Production Function Parameters and Testing for Efficiency. Econometrica 23: 325-326.

Hoch, I. (1958) Simultaneous Equation Bias in the Context of the Cobb-Douglas Production Function. Econometrica 26: 566-758.

Hoch, I. (1962) Estimation of Production Function Parameters Combining, Time Series and Cross-Section Data. Econometrica 30: 34-45.

Hoch, I. (1976) Return to Scale in Farming: Future Evidence. American Journal of Agricultural Economics 58: 745-749. 
Kalirajan, K. P. (1991) The Importance of Efficient Use in the Adoption of Technology: A Micro Panel Data Analysis. Journal of Productivity Analysis 2: 113-126.

Karamat, Ali, and A. Hameed (1996) Technical Change, Technical Efficiency, and Their Impact on Input Demand in the Agricultural and Manufacturing Sectors. The Pakistan Development Review 35:3 215-228.

Khan, S. R. A. (1985) Strategy of Increasing Wheat Production in the Barani Areas. Department of Agriculture, Government of the Punjab, Lahore.

Khan, A. M., M. Ahmad, M. I. Khan, and Z. Ahmad (1990) Livestock Management and Productivity Issues in Three Main Rainfed Ecologies of Pakistan: Results from Exploratory Surveys, 1985-1990. In A. S. Haider, Z. Hussain, R. McConnen and S. J. Malik (eds) Agricultural Strategies in the 1990s: Issues and Policies. Islamabad: Pakistan Agricultural Social Scientists.

Kumbhakar, S. C. (1990) Production Frontier, Panel Data and Time Varying Technical Inefficiency. Journal of Econometrics 27: 201-11.

Lall, S. (1993) Understanding Technology Development. Development and Change 24: 719-53.

Lovell, C. A. K. (1993) Production Frontiers and Productive Efficiency. In H. O. Fried, C. A. K. Lovell and Schmidt (eds) The Measurement of Productive Efficiency Techniques and Applications. New York: Oxford University Press. 3-67.

Mahmood, A. (1995) Economics of Barani (Rainfed) Farming and Farm Household Production Behaviour in Pakistan. The Pakistan Development Review 34:4 901-12.

Meeusen, W., and J. van den Broeck (1977) Efficiency Estimation from Cobb-Douglas Production Function with Composed Error. International Economic Review 18: 435-44.

Mundlak, Yair (1961) Empirical Production Function Free of Management Bias. Journal of Farm Economics 43: 44-56.

Mundlak,Yair (1978) On the Pooling of Time Series and Cross-Section Data. Econometrica 46: 69-85.

National Fertiliser Development Centre (1996) Fertiliser Use on Wheat: Farm Level Survey Rabi 1991-92. Islamabad. (Mimeographed.)

Pakistan, Government of (Various Issues) Agricultural Statistics of Pakistan. Food and Agriculture Division (Planning Unit). Islamabad: Ministry of Food, Agriculture and Cooperatives.

Pakistan, Government of (1998) Economic Survey 1997-98. Islamabad: Finance Division.

Pitt, M., and L. F. Lee (1981) The Measurements and Sources of Technical Efficiency in the Indonesian Weaving Industry. The Journal of Development Economics 9: 43-64.

Punjab, Government of (Various Issues) Development Statistics of Punjab. Lahore: Punjab Bureau of Statistics.

Qureshi, S. K. (1963) Rainfall, Acreage, and Wheat Production in West Pakistan: A Statistical Analysis. The Pakistan Development Review 3:4 566-93. 
Ramanathan, R. (1992) Introductory Econometrics with Applications. New York: The Dryden Press.

Richmond, J. (1974) Estimating the Efficiency of Production. International Economic Review 15: 515-521.

Schmidt, P. (1976) On the Statistical Estimation of Parametric Frontier Production Function. The Review of Economics and Statistics 58: 238-239.

Schmidt, P., and R. C. Sickles (1984) Production Frontier and Panel Data. Journal of Business and Economic Statistics 2: 367-374.

Seale, J. L. Jr. (1990) Estimated Stochastic Frontier Systems with Unbalanced Panel Data: The Case of Floor Tile Manufacturers in Egypt. Journal of Applied Econometrics 5: 59-74.

Timmer, C. P. (1971) Using a Probabilistic Frontier Function to Measure Technical Efficiency. Journal of Political Economy 79: 776-794.

Timmer, C. P. (1970) One Measuring Technical Efficiency. Food Resources Institute Studies in Agriculture Economics, Trade and Development 9: 98-171.

Wizarat, S. (1981) Technical Change in Pakistan Agriculture: 1953-54 to 1978-79. The Pakistan Development Review 20:4 427-445. 